\title{
Skuteczność lenalidomidu u chorego na szpiczaka plazmocytowego współistniejącego z zespołem mielodysplastycznym związanym z izolowaną delecją chromosomu 5q-
}

\author{
The efficacy of lenalidomide in the patient with plasma \\ cell myeloma coexisting with myelodysplatic syndrome \\ associated with isolated del 5 q-
}

\author{
Agata Malenda ${ }^{1}$, Agnieszka Kołkowska-Leśniak ${ }^{1}$, Anna Szumera-Ciećkiewicz ${ }^{3}$, \\ Ewa Lech-Marańda ${ }^{1,2}$, Krzysztof Warzocha ${ }^{1}$ \\ ${ }^{1}$ Klinika Hematologii, Instytut Hematologii i Transfuzjologii, Warszawa \\ ${ }^{2}$ Klinika Hematologii i Transfuzjologii, Centrum Medyczne Kształcenia Podyplomowego, Warszawa \\ ${ }^{3}$ Zakład Diagnostyki Hematologicznej, Instytut Hematologii i Transfuzjologii, Warszawa
}

\begin{abstract}
Streszczenie
Ze wzgledu na znaczne wydtużenie przeżycia chorych na szpiczaka plazmocytowego (PCM) coraz częściej obserwuje sie u nich występowanie innych nowotworów. Klasycznym przyktadem jest rozwój wtórnych do zastosowanej wcześniej chemioterapii zespotów mielodysplastycznych (MDS). $W$ niniejszej pracy opisano rzadki przypadek chorego, u którego stwierdzono wspótistnienie PCM oraz MDS zwiazanym z izolowana del 5q-(MDS 5q-). Zastosowanie lenalidomidu pozwolito na uzyskanie cześciowej remisji cytogenetycznej MDS oraz cześciowej remisji PCM.
\end{abstract}

Słowa kluczowe: szpiczak plazmocytowy, zespół mielodysplastyczny, delecja 5q-, lenalidomid

Hematologia 2016; 7, 1: 77-84

\begin{abstract}
Treatment-related extension of survival has recently been observed in patients with plasma cell myeloma (PCM). However, chemotherapy also increases he incidence of other cancers for this patient group; myelodysplastic syndrome (MDS) being a classic example. A rare case-study is presented of a patient diagnosed with PCM coexisting with MDS associated with isolated del 5q-(MDS 5q-). After lenalidomide treatment, partial remission from PCM was observed, also accompanied by partial cytogenic remission of MDS $5 q-$.
\end{abstract}

Key words: plasma cell myeloma, myelodysplatic syndrome, deletion $5 q-$, lenalidomide

Hematologia 2016; 7, 1: 77-84

\section{Wprowadzenie}

Szpiczak plazmocytowy (PCM, plasma cell myeloma) to nowotwór wywodzący się ze zróżnicowanych limfocytów B, dla którego charakte- rystyczny jest naciek szpiku przez plazmocyty produkujące białko monoklonalne oraz uwalniające cytokiny stymulujące destrukcję kostną. Stanowi on 10-15\% wszystkich nowotworów hematologicznych $z$ częstością zachorowania 4-6 przypadków/ 
/100 000 osób/rok, zaś mediana wieku przy rozpoznaniu choroby wynosi 65-70 lat [1]. Obecnie objawowy PCM rozpoznaje się niezależnie od klasycznych objawów CRAB (calcium increased, renal insufficency, anemia, bone lesions), w przypadku gdy występuje co najmniej 60-procentowy naciek z komórek plazmatycznych $\mathrm{w}$ szpiku kostnym, stosunek wolnych łańcuchów lekkich (FLC, free light chain) $\kappa / \lambda$ w surowicy wynosi 100 i więcej lub stwierdza się co najmniej dwie zmiany ogniskowe o minimum $5 \mathrm{~mm}$ średnicy uwidocznione metodą rezonansu magnetycznego [2].

Zespoły mielodysplastyczne (MDS, myelodysplastic syndromes) są heterogenną grupą nowotworów cechujących się nieefektywną hematopoezą $z$ cechami dysplazji, tendencją do cytopenii we krwi obwodowej oraz możliwością transformacji $\mathrm{w}$ ostrą białaczkę szpikową (AML, acute myeloid leukemia). Częstość zachorowań na MDS szacuje się na 5 przypadków/100 000 osób/rok, przy czym u osób powyżej 70. roku życia wzrasta ona do 22-45 przypadków/100 000 osób/rok [3].

Zespół mielodysplastyczny może mieć charakter pierwotny, jeżeli nie stwierdza się wcześniejszego narażenia na działanie czynników mutagennych. Wtórne MDS są rozpoznawane u osób leczonych uprzednio $z$ powodu innego nowotworu, zwłaszcza lekami alkilującymi, inhibitorami topoizomerazy, radioterapią oraz narażonych na środowiskowe czynniki toksyczne.

W niniejszej pracy opisano przypadek chorego, u którego wystąpiła koincydencja PCM oraz MDS związanego $\mathrm{z}$ izolowaną delecją chromosomu 5q- (MDS 5q-).

\section{Opis przypadku}

W czerwcu 2012 roku u 75-letniego, dotychczas nieleczonego, pacjenta rozpoznano PCM IgA typu $\kappa$ w stopniu zaawansowania IIIA według Durie-Salmona oraz w stopniu 3. według Międzynarodowego Wskaźnika Prognostycznego (ISS, International Scoring System). W badaniu immunofiksacyjnym surowicy krwi wykryto białko monoklonalne klasy IgA typu $\kappa$ w stężeniu 2,92 g/dl. W badaniu immunofiksacyjnym moczu stwierdzono obecność bardzo delikatnej frakcji odpowiadającej lekkiemu łańcuchowi immunoglobulinowemu typu $\kappa$. Stężenie białka całkowitego w moczu wynosiło $5,6 \mathrm{mg} / \mathrm{dl}$, a jego wydalanie dobowe $0,1 \mathrm{~g}$. Stężenie immunoglobulinowych FLC typu $\kappa$ w surowicy wynosiło $335 \mathrm{mg} / \mathrm{l}$, zaś typu $\lambda-23,90 \mathrm{mg} / \mathrm{l}$. Stosunek FLC $\kappa / \lambda$ wyniósł 14,00 . W badaniach biochemicznych oznaczono: prawidłowe stężenie wapnia, pod- wyższone stężenie kreatyniny 1,51 mg/dl, klirens kreatyniny według Cockrofta-Gaulta $51,42 \mathrm{ml} / \mathrm{min}$, przyspieszony odczyn opadania krwinek czerwonych $120 \mathrm{~mm} / \mathrm{h}$, stężenie albumin $3,65 \mathrm{mg} / \mathrm{dl}$, stężenie $\beta_{2}$-mikroglobuliny $6,10 \mathrm{mg} / \mathrm{l}$. W trepanobiopsji opisano szpik o komórkowości odpowiedniej do wieku, E:M 1:4-5; linię granulocytową z odmłodzeniem, brak komórek z ekspresją CD34; znacznie zubożałą linię czerwonokrwinkową; mieszczącą się w normie liczbę megakariocytów, polimorfizm postaci. Ponadto stwierdzono nacieki rozproszonych oraz znajdujących się w skupieniach komórek plazmatycznych stanowiących 10-15\% wszystkich komórek. W badaniu radiologicznym kośćca nie uwidoczniono ognisk osteolizy; opisano cechy zaniku kostnego oraz wielopoziomowej dyskopatii na poziomach C3-C7 i L5-S1.

W momencie rozpoznania chory zgłaszał utrzymujące się od kilku miesięcy osłabienie; negował objawy stenokardialne oraz krwawienie $z$ przewodu pokarmowego. W morfologii krwi obwodowej stwierdzano wówczas leukopenię 1. stopnia (liczba krwinek białych [WBC, white blood cells] 3,1 G/1) według Światowej Organizacji Zdrowia (WHO, World Health Organisation), prawidłową liczbę płytek krwi (PLT, platelets) wynoszącą $223 \mathrm{G} / 1$ oraz niedokrwistość normocytową 2. stopnia według WHO (liczba krwinek czerwonych [RBC, red blood count $]$ 2,58 G/l, stężenie hemoglobiny [Hb] 8,2 g/dl, hematokryt 25\%, średnia objętość krwinki [MCV, mean corpuscular volume] 95,8 fl, średnia masa hemoglobiny w erytrocytach [MCH, mean corpuscular hemoglobin] 31,7 pg, średnie stężenie hemoglobiny $\mathrm{w}$ erytrocytach [MCHC, mean corpuscular hemoglobin concentration] 33,1 g/dl).

W celu ustalenia przyczyny niedokrwistości wykonano badania laboratoryjne, w których stwierdzono prawidłowe stężenie żelaza, podwyższone stężenie ferrytyny ( $1457 \mathrm{ng} / \mathrm{ml})$, utajoną zdolność wiązania żelaza (UIBC, unsaturated iron binding capacity) poniżej $20 \mu \mathrm{g} / \mathrm{dl}$, nieoznaczalną całkowitą zdolność wiązania żelaza (TIBC, total iron binding capacity), nieznacznie obniżone stężenie transferyny $(131,9 \mathrm{mg} / \mathrm{dl})$, stężenia witaminy $\mathrm{B}_{12}$ oraz kwasu foliowego w normie, stężenie erytropoetyny wynoszące $292 \mathrm{mjm} . / \mathrm{ml}$. W surowicy krwi wykryto alloprzeciwciała anty- $\mathrm{C}^{\mathrm{w}}$ z układu Rh. Nie wykazano biochemicznych cech aktywnej hemolizy. Ponadto w gastroskopii zaobserwowano nadżerkowe zapalenie błony śluzowej części wpustowej żołądka oraz refluksowe zapalenie przełyku w stopniu zaawansowania A według klasyfikacji Los Angeles. Podczas kolonoskopii uwidoczniono prawidłowy obraz błony śluzowej całego jelita grubego. 
W badaniu ultrasonograficznym jamy brzusznej nie stwierdzono hepato- ani splenomegalii; opisano zmiany pozapalne w obu nerkach oraz złóg o średnicy $12 \mathrm{~mm}$ w okolicy przedszyjkowej pęcherzyka źółciowego. W zapisie elektrokardiograficznym opisano liczne dodatkowe pobudzenia nadkomorowe i utrwalone migotanie przedsionków. W badaniu echokardiograficznym nie zobrazowano istotnych odchyleń; ogólna frakcja wyrzutowa (EF, ejection fraction) wynosiła $67 \%$.

We wrześniu 2012 roku, ze względu na obecność objawów CRAB (wzrost wartości kreatyniny $>2 \mathrm{mg} / \mathrm{dl}$, niedokrwistość), chorego zakwalifikowano do leczenia pierwszej linii według schematu CTD (cyklofosfamid, talidomid, deksametazon). Chory otrzymał łącznie 3 cykle terapii, po których stwierdzono stabilizację choroby. Nie uzyskano uniezależnienia od przetoczeń koncentratu krwinek czerwonych (kkcz). Ze względu na zgłaszane przez chorego dolegliwości bólowe, zlokalizowane w kończynach dolnych, przeprowadzono konsultację neurologiczną. Rozpoznano polineuropatię ruchową 1. stopnia, neuropatię czuciową 1. stopnia, zespó1 pozapiramidowy 2 . stopnia oraz oczopląs 1 . stopnia według WHO. Zadecydowano o zaprzestaniu dalszego leczenia talidomidem. W grudniu 2012 roku dokonano oceny hematologicznej. W badaniu histopatologicznym opisano szpik o komórkowości przeważnie nieco zwiększonej w stosunku do wieku, ogniskowo hipoplastyczny. Linia czerwonokrwinkowa była zubożała, $z$ zachowanym dojrzewaniem. Linię granulocytową cechowało odmłodzenie. Liczba megakariocytów pozostawała w normie $z$ niewielkim polimorfizmem postaci. Widoczne były liczne złogi hemosyderyny. Nacieki komórek plazmatycznych stanowiły $10-15 \%$. Z powodu cech hipoplazji podjęto decyzję o odstawieniu cyklofosfamidu. Chorego zakwalifikowano do leczenia pulsami $z$ deksametazonu oraz do terapii chelatującej deferoksaminą. Stężenie ferrytyny wynosiło wówczas $1576 \mathrm{ng} / \mathrm{ml}$.

Do maja 2013 roku utrzymywała się stabilizacja choroby podstawowej. Jednocześnie obserwowano pogłębianie się niedokrwistości (najniższe stężenie $\mathrm{Hb}$ wynosiło $5,3 \mathrm{~g} / \mathrm{dl}$ ). Chory wymagał przetaczania 4-5 jednostek kkcz w ciągu miesiąca oraz leczenia chelatującego. Ze względu na niewspółmierność stopnia nacieczenia szpiku przez komórki plazmatyczne do stopnia niedokrwistości wykonano kolejne badania diagnostyczne. Wykluczono niedoborowe przyczyny niedokrwistości, niedokrwistość dyserytropoetyczną typu II, sferocytozę wrodzoną oraz inne membranopatie.

W sierpniu 2013 roku, w kolejnym badaniu histopatologicznym szpiku, opisano śródmiąższo- we nacieki z komórek plazmatycznych stanowiące 15-20\% wszystkich komórek. Linia czerwonokrwinkowa była zubożała, reprezentowana przez nieliczne wyspy i rozproszone erytroblasty, $z$ odmłodzeniem, obecne były także postacie dojrzałe. Liczba megakariocytów pozostawała w normie; stwierdzono polimorfizm postaci i nieprawidłową morfologię megakariocytów, wśród których przeważały postacie nieco mniejsze $z$ hipolobulacją lub brakiem lobulacji jąder komórkowych. W podścielisku obserwowano liczne złogi hemosyderyny. Wynik barwienia na amyloid był negatywny. Ponadto opisano śródmiąższowe skupienia limfocytów B i T stanowiące około $20 \%$ wszystkich komórek (ryc. 1). W badaniu cytogenetycznym szpiku we wszystkich analizowanych metafazach stwierdzono delecję fragmentu ramienia długiego chromosomu 5. pary, del(5)(q22q34), jako jedyną zmianę kariotypową. Wyniki przeprowadzonych badań pozwoliły na rozpoznanie MDS 5q-.

W październiku 2013 roku rozpoczęto leczenie lenalidomidem $\mathrm{w}$ dawce $10 \mathrm{mg} /$ dobę. W listopadzie 2013 roku u chorego wystąpiła neutropenia 4. stopnia według WHO powikłana zapaleniem płuc. Wstrzymano leczenie lenalidomidem. Podawano szerokospektralne antybiotyki i czynnik stymulujący tworzenie kolonii granulocytów (G-CSF, granulocyte-colony stimulating factor); chory wymagal hospitalizacji. $\mathrm{W}$ badaniu radiologicznym klatki piersiowej stwierdzono zagęszczenia miąższowe w górnym płacie lewego płuca. Na podstawie przeprowadzonej diagnostyki wykluczono gruźlicę płuc. Leczenie lenalidomidem rozpoczęto ponownie w styczniu 2014 roku $\mathrm{w}$ dawce $5 \mathrm{mg} /$ dobę. W kontrolnej morfologii krwi po 2 tygodniach leczenia uzyskano następujące wartości: WBC 6,46 G/1 (w tym liczba neutrofilów 4,30 G/l), stężenie Hb 10,7 g/dl, RBC 3,55 G/l, liczba PLT 176 G/l. Terapia lenalidomidem była powikłana małopłytkowością w 3 . stopniu według WHO. Okresowo u chorego występowała drobnogrudkowa wysypka skórna w 2. stopniu według WHO, $z$ dobrą odpowiedzią na stosowane leki przeciwhistaminowe. Po 4 miesiącach leczenia uzyskano uniezależnienie od przetoczeń kkcz, a po 5 miesiącach - normalizację parametrów morfologii krwi. Ze względu na nasilenie się wysypki z towarzyszącym, uporczywym świądem dawkę lenalidomidu zmniejszono do $5 \mathrm{mg}$ /dobę co 2 . dzień, przy której obserwowano ustąpienie dolegliwości.

We wrześniu 2014 roku dokonano oceny hematologicznej. W badaniach biochemicznych utrzymywały się cechy przewlekłej choroby nerek ze stężeniem kreatyniny w surowicy krwi 1,82 mg/dl 

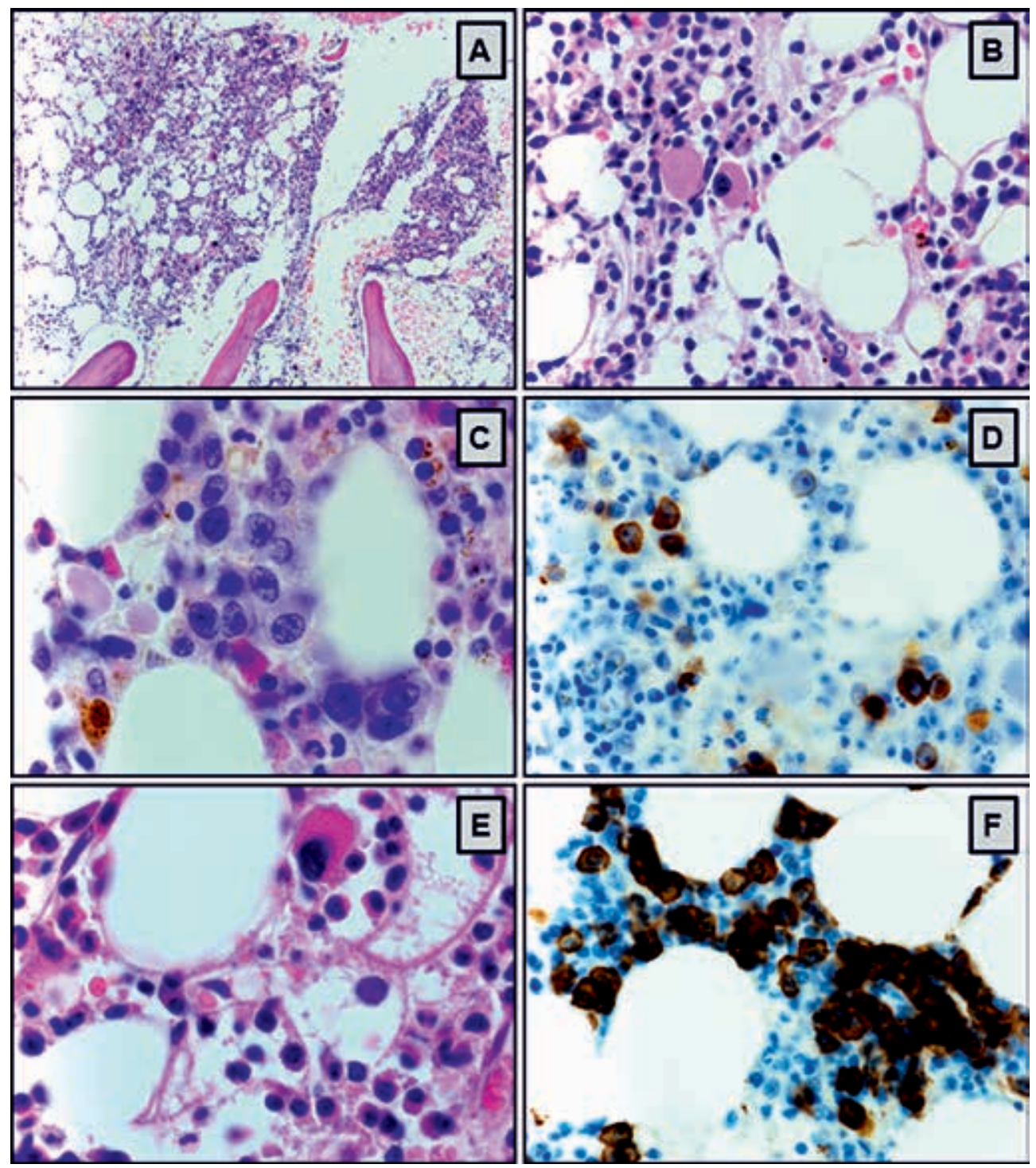

Rycina 1A-F. Obraz mikroskopowy szpiku kostnego z cechami odpowiadającymi rozpoznaniu zespołu mielodysplastycznego związanego z izolowaną delecją 5q- z towarzyszącym naciekiem szpiczaka plazmocytowego: A. Szpik o komórkowości odpowiedniej do wieku, liczne polimorficzne megakariocyty (barwienie hematoksyliną-eozyną [HE], powiększenie 40 ×); B, C. Nieprawidłowa morfologia megakariocytów — mniejsze postacie z hipolobulacją lub brakiem jąder komórkowych $(\mathrm{HE}, 60 \times$ oraz $100 \times$ ); D, E. Zubożała linia czerwonokrwinkowa, reprezentowana przez nieliczne wyspy i rozproszone erytroblasty, z odmłodzeniem (CD71, $60 \times$ oraz HE $60 \times$ ); F. Śródmiąższowe nacieki z komórek plazmatycznych stanowiące do 20\% wszystkich komórek szpiku (CD138, $60 \times$ )

Figure 1A-F. Microscope image of a bone marrow showing characteristic features of the myelodysplastic syndrome associated with isolated $5 q$ deletion with accompanying plasme cell myeloma infiltration: A. Marrow cellularity appropriate to age and many polymorphic megakaryocytes (hematoxylin-eosin staining [HE]; magnification $\times 40$ ); $\mathbf{B}, \mathbf{C}$. Abnormal megakaryocyte morphology - hyperlobular and anucleate types $(\mathrm{HE}, 60 \times$ and $100 \times)$; D, E. Impoverished red blood cell line represented by few and scattered erythroblast islands of rejuvenation (CD71, $60 \times$, and $\mathrm{HE} \times 60)$; F. Interstitial infiltrates from plasma cells constituting up to $20 \%$ of all bone marrow cells $($ CD $138,60 \times)$

i wskaźnikiem filtracji kłębuszkowej (GFR, glomerular filtration rate) $36,4 \mathrm{ml} / \mathrm{min} / 1,73 \mathrm{~m}^{2}$. Stwierdzano obecność białka monoklonalnego IgA typu $\kappa$ w surowicy krwi w stężeniu $1,91 \mathrm{~g} / \mathrm{dl}$. W badaniu cytogenetycznym szpiku, w 3 spośród 20 analizo- wanych metafaz, stwierdzono delecję fragmentu ramienia długiego chromosomu 5. pary, del(5) (q22q34). W porównaniu $z$ poprzednim badaniem kariotypu zaobserwowano częściową remisję cytogenetyczną MDS 5q-. W badaniu trepanobiopsyjnym 
szpik był przeważnie hipoplastyczny, $z$ utkaniem krwiotwórczym zajmującym 10-15\% jamek szpikowych. Śódmiąższowe nacieki z komórek plazmatycznych stanowiły $10-20 \%$ wszystkich komórek. Linia granulocytowa miała zachowane dojrzewanie. Linia czerwonokrwinkowa była zubożała, z cechami nieznacznej dyserytropoezy. Liczba megakariocytów była obniżona, z przewagą postaci mniejszych $z$ hipolobulacją jądra. W podścielisku stwierdzono liczne złogi hemosyderyny. Kontynuowano leczenie lenalidomidem w dawce $5 \mathrm{mg} /$ dobę co 2. dzień.

Kolejną ocenę hematologiczną wykonano w sierpniu 2015 roku. W badaniu trepanobiopsyjnym i badaniu cytogenetycznym obraz pozostawał stabilny w odniesieniu do wyników z września 2014 roku. Nastąpiło obniżenie stężenia białka monoklonalnego IgA typu $\kappa$ do $0,52 \mathrm{~g} / \mathrm{dl}$, nie uzyskano natomiast poprawy parametrów wydolności nerek. Obie choroby spełniały kryteria częściowej remisji.

\section{Dyskusja}

Pierwsze wzmianki na temat MDS 5q- pojawily się w piśmiennictwie w 1974 roku. Opisano wówczas chorobę hematologiczną, której charakterystyczną cechą była delecja długiego ramienia chromosomu 5. pary [4]. W 1994 roku podjęto pierwszą próbę zdefiniowania tego zespołu. Zwrócono uwagę na nawrotowy charakter niedokrwistości, której towarzyszyła delecja długiego ramienia chromosomu 5. pary jako jedyna zmiana w kariotypie [5]. W 2002 roku MDS 5q- wyodrębniono jako oddzielną jednostkę chorobową w klasyfikacji MDS według WHO. Obejmuje on pacjentów $z$ izolowaną delecją 5q31-33 i obecnością w szpiku kostnym mniej niż $5 \%$ blastów oraz niedokrwistością, której często towarzyszy nadpłytkowość [6]. Kryteria rozpoznania MDS 5q- przedstawiono w tabeli 1. Należy pamiętać, że delecja $5 q$ występuje u około $12 \%$ pacjentów

Tabela 1. Kryteria rozpoznania zespołu mielodysplastycznego związanego z izolowaną delecją $5 q-$

\begin{tabular}{ll}
\hline Krew obwodowa & Szpik kostny \\
\hline Niedokrwistość & $\begin{array}{l}\text { Prawidłowa lub zwiększona } \\
\text { liczba megakariocytów } \\
\text { z jądrami o zmniejszonej } \\
\text { liczbie płatów }\end{array}$ \\
$<5 \%$ blastów & $<5 \%$ blastów \\
Prawidłowa lub zwiększona & Brak pałek Auera \\
liczba płytek krwi & Izolowana del(5q) \\
\hline
\end{tabular}

z MDS oraz jest najczęstszą nieprawidłowością cytogenetyczną w tej grupie chorych [7]. Typowy MDS 5q- z izolowaną delecją 5q31-33 stanowi jednak mniej niż 5\% wszystkich przypadków MDS [8]. Jest rozpoznawany głównie u starszych kobiet i wiąże się ze stosunkowo dobrym rokowaniem i niewielką skłonnością do transformacji w AML [9].

W 2005 roku amerykańska Agencja ds. Żywności i Leków (FDA, Food and Drug Administration) zaaprobowała lenalidomid do leczenia chorych na MDS zależnych od przetoczeń kkcz z grupy niskiego lub pośredniego-1 ryzyka według Międzynarodowego Sytemu Prognostycznego (IPSS, International Prognostic Scoring System), przebiegającym $z$ del(5q) jako izolowaną zmianą cytogenetyczną lub ze wspólistniejącymi innymi zaburzeniami. Badanie rejestracyjne II fazy przeprowadzono u 148 chorych na MDS. Pierwszych 46 pacjentów otrzymywało lenalidomid w dawce $10 \mathrm{mg} /$ dobę przez $21 \mathrm{dni}$, w cyklach 28-dniowych, zaś pozostali chorzy przyjmowali lenalidomid w dawce $10 \mathrm{mg} /$ dobę podawany codziennie. Po 24 tygodniach terapii $67 \%$ pacjentów uniezależniło się od przetoczeń kkcz, a u kolejnych 9\% doszło do zmniejszenia o co najmniej $50 \%$ konieczności przetoczeń kkcz. Mediana czasu do uzyskania odpowiedzi hematologicznej, wyrażającej się uniezależnieniem od przetoczeń kkcz, wyniosła 4,6 tygodnia, zaś mediana utrzymywania się odpowiedzi klinicznej - 44 tygodnie. Co więcej, u $45 \%$ chorych spośród 85 poddanych analizie odnotowano całkowitą remisję cytogenetyczną, niezależnie od złożoności wyjściowych nieprawidłowości chromosomowych. Najczęstszymi działaniami niepożądanymi 3. i 4. stopnia według WHO w całej badanej grupie były neutropenia oraz małopłytkowość. Dotyczyły one, odpowiednio, $55 \%$ oraz $44 \%$ pacjentów. Odnotowano również większą częstość niedokrwistości (7\%), wysypek skórnych (6\%) oraz biegunek (3\%). Podobnie jak u opisywanego pacjenta większość objawów niepożądanych pojawiła się w pierwszych 8 tygodniach terapii. Choć opisywane objawy niepożądane wymagały modyfikacji dawki lenalidomidu, to ostatecznie wiązały się z lepszą odpowiedzią na leczenie $[10,11]$. W randomizowanym badaniu klinicznym III fazy, przeprowadzonym w grupie 205 zależnych od przetoczeń chorych na MDS niskiego lub pośredniego-1 ryzyka $z$ delecją 5q31, potwierdzono, że pacjenci otrzymujący lenalidomid w dawce $10 \mathrm{mg}$ /dobę lub $5 \mathrm{mg} /$ dobę statystycznie częściej osiągają niezależność od przetoczeń kkcz niż osoby z grupy otrzymującej placebo $(56,1 \%$ v. $42,6 \%$ v. 5,9\%; $\mathrm{p}<0,001)$. Wykazano równiez, że uzyskanie odpowiedzi na leczenie obniża ryzyko zgonu oraz progresji do AML [12]. 
Szpiczak plazmocytowy pozostaje nawrotowym i nieuleczalnym nowotworem, jednak zastosowanie leków nowej generacji, w tym leków immunomodulujących (IMiDs, immunomodulatory drugs) oraz inhibitorów proteasomu, pozwoliło na znaczące wydłużenie całkowitego przeżycia (OS, overall survival) chorych [13]. W pierwszej linii leczenia u chorych na PCM, niekwalifikujących się do procedury autologicznego przeszczepienia krwiotwórczych komórek macierzystych (auto-HSCT, autologous hematopoietic stem cell transplantation), stosuje się protokoły terapeutyczne oparte na melfalanie $\mathrm{w}$ połączeniu $\mathrm{z}$ takimi lekami, jak bortezomib, talidomid czy lenalidomid. Alternatywnie można stosować protokół CTD w zmniejszonych dawkach. W Polsce do 2015 roku stosowano głównie protokół MPT (melfalan, prednizon, talidomid), ale uzyskanie refundacji leczenia bortezomibem - początkowo w ramach programu lekowego, a następnie $z$ katalogu chemioterapii - pozwoliło na zastosowanie tego leku w pierwszej linii leczenia w schematach wielolekowych, takich jak na przykład VMP (bortezomib, melfalan, prednizon).

Ponadto w lutym 2015 roku Europejska Agencja Leków (EMA, European Medicines Agency) zatwierdziła stosowanie lenalidomidu $\mathrm{w}$ terapii wcześniej nieleczonych chorych na PCM, którzy nie kwalifikują się do auto-HSCT [14], jednak w tym wskazaniu lek ten nie jest jeszcze refundowany w Polsce. Opisany w tej pracy pacjent w pierwszej linii leczenia został zakwalifikowany do terapii według schematu CTD. Początkowo nie zakładano wspólistnienia MDS z PCM, jednak — ze względu na utrzymującą się niedokrwistość mimo stosowanego leczenia - poszerzono diagnostyke oraz rozpoznano współwystępowanie obu nowotworów.

Ze względu na postęp w leczeniu i znaczne wydłużenie OS chorych na PCM coraz częściej rozpoznaje się u nich kolejne nowotwory. Szacuje się, że obecnie występują one u 2-10\% pacjentów z PCM [15]. Spośród opisywanych przypadków $22 \%$ stanowiły nowotwory hematologiczne [16]. Wśród rozpoznawanych kolejnych nowotworów wyróżnia się przypadki pierwotne oraz wtórne do zastosowanej terapii. Pierwsze doniesienia na temat rozwoju MDS u chorych na PCM pojawiły się już w latach 70 . XX wieku. W pracy opublikowanej na łamach czasopisma „New England Journal of Medicine" [17] zaprezentowano serię 4 przypadków dotyczących chorych na PCM leczonych melfalanem przez 30-57 miesięcy, u których doszło do rozwoju ostrej białaczki mielomonocytowej. Uważa się, że u 10-20\% pacjentów poddanych leczeniu alkilującemu z powodu PCM 10 lat po zakończenia terapii rozwinie się MDS lub AML [18]. Obliczono, że standaryzowany współczynnik zachorowalności (SIR, standardized incidence ratio) na AML związanej $z$ terapią u pacjentów z PCM wynosi 10,43 (95-proc. przedział ufności [CI, confidence interval] 7,99-13,37), przy czym wskaźnik ten dla grupy wszystkich pacjentów $\mathrm{z}$ nowotworami jest równy 4,7 (95\% CI 4,38-5,04) [19]. Uważa się więc, że rozwój wtórnego MDS/AML u pacjenta z PCM jest dość powszechnym zjawiskiem. Początkowo opisywano głównie przypadki wynikające $z$ przedłużonej terapii lekami alkilującymi, jednak w 2012 roku opublikowano kilka prac, w których wykazano, że również terapia lenalidomidem lub bortezomibem może się wiązać ze zwiększonym ryzykiem rozwoju kolejnych nowotworów [20-23].

Okazuje się jednak, że zastosowana terapia jest tylko jednym $z$ wielu czynników, które mogą prowadzić do ich rozwoju. Thomas i wsp. [24], w pracy opublikowanej na łamach czasopisma „Blood”, zaproponowali model powstawania kolejnych nowotworów, w którym uwzględnili czynniki związane $z$ terapią, czynniki związane $z$ PCM, czynniki genetyczne, czynniki środowiskowe oraz behawioralne (ryc. 2). W przypadku pacjenta opisywanego w niniejszym artykule trudno zakładać, że do rozwoju MDS 5q- przyczyniła się 3-miesięczna chemioterapia według schematu CTD. Nie można jednak wykluczyć udziału innych czynników, na przykład związanych $z$ samym zachorowaniem na

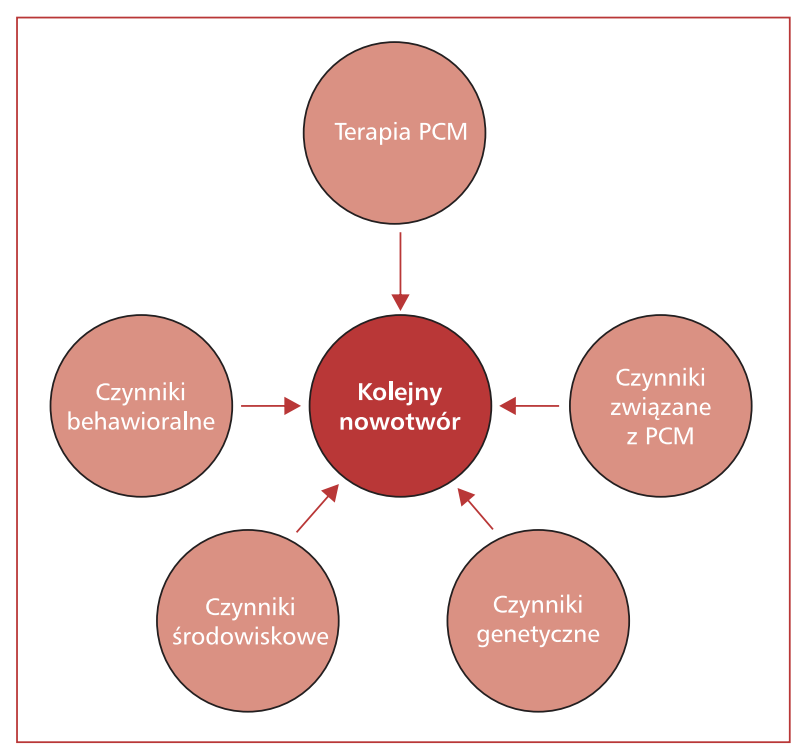

Rycina 2. Model powstawania kolejnych nowotworów u chorych na szpiczaka plazmocytowego (PCM, plasma cell myeloma) zaproponowany przez Thomasa i wsp. [24] 
PCM. W badaniu przeprowadzonym w populacji szwedzkiej dowiedziono, że pacjenci $z$ gammapatią monoklonalną o nieustalonym znaczeniu (MGUS, monoclonal gammapathy of uncertain significance) są 8-krotnie bardziej narażeni na rozwój MDS/AML. Co więcej, ryzyko to wzrasta u chorych z MGUS IgG lub IgA, u których stężenie białka monoklonalnego przekracza 1,5 g/dl [25]. Należy wziąć również pod uwagę czynniki związane $z$ gospodarzem, czyli tak zwane host-related factors. Predyspozycje genetyczne danego pacjenta odpowiadają nie tylko za reakcję na zastosowaną terapię, ale również za naprawę DNA, a tym samym skłonność do rozwinięcia się wtórnych nowotworów [26]. Dużą rolę odgrywają również czynniki pozagenetyczne, do których zalicza się między innymi wiek, rasę, wydolność narządów wewnętrznych, choroby współistniejące czy stosowane leki. Dla rozwoju MDS/AML duże znaczenie może mieć także mikrośrodowisko szpiku kostnego, w którym znajdują się między innymi białka przestrzeni pozakomórkowej oraz takie komórki, jak: macierzyste, śródnabłonkowe szpiku kostnego, układu odpornościowego, erytrocyty, osteoklasty oraz osteoblasty. Między plazmocytami oraz składnikami mikrośrodowiska szpiku zachodzą liczne interakcje, które odgrywają istotną rolę w patogenezie PCM. Skutkują one między innymi aktywacją szlaków przekazywania sygnałów związanych ze wzrostem, przeżyciem oraz migracją komórek, opornością na leki, osteoklastogenezą czy angiogenezą [27]. Bardzo prawdopodobne wydaje się zatem, że zmiany zachodzące $\mathrm{w}$ mikrośrodowisku szpiku mogą również prowadzić do większej podatności na rozwój MDS/AML [24].

Niewiele wiadomo na temat pierwotnego współwystępowania PCM oraz MDS. W piśmiennictwie opisy takich przypadków pojawiają się rzadko [28-30]. Florensa i wsp. [31] oszacowali, że tylko u $1 \%$ pacjentów $z$ MDS można dodatkowo rozpoznać nowotwór wywodzący się z limfocytów B. Wśród 1198 przeanalizowanych przypadków takie rozpoznanie dotyczyło 14 osób, przy czym PCM wystąpił u 3. Współwystępowanie PCM oraz MDS $5 \mathrm{q}-$ opisuje się w literaturze jeszcze rzadziej. W 2000 roku opublikowano pierwszy opis przypadku, w którym oba nowotwory rozpoznano jednoczasowo. Przedstawiono w nim 74-letnią chorą diagnozowaną $\mathrm{z}$ powodu stwierdzonej $\mathrm{w}$ rutynowych badaniach krwi pancytopenii (WBC 3,3 G/l, stężenie Hb 9,8 g/dl, PLT 117 G/l) z makrocytozą (MCV 108 fl). Początkowo podejrzewano PCM, jednak wyniki badania immunofiksacji białek krwi oraz moczu okazały się negatywne. Po 3 latach u pa- cjentki doszło do pogłębienia się niedokrwistości oraz uzależnienia od przetoczeń kkcz. Na podstawie badania cytogenetycznego rozpoznano MDS 5q-. Dodatkowo, ze względu na wystąpienie patologicznego złamania VI żebra, ponownie przeprowadzono badania diagnostyczne oraz rozpoznano PCM. $\mathrm{W}$ niedługim czasie od rozpoznania pacjentka zmarła $z$ powodu licznych powikłań infekcyjnych [32]. Drugi opis przypadku, w którym zaprezentowano wspólistnienie PCM oraz MDS 5q-, został opublikowany w 2013 roku. U 72-letniego chorego rozpoznano bezobjawowy PCM IgA typu 1. Dwa lata później, z powodu pogłębienia się niedokrwistości, poszerzono diagnostykę i dodatkowo rozpoznano współistnienie MDS 5q-. W badaniu cytogenetycznym opisywano wówczas 46, XX, del (5)(q13q33). Początkowo pacjenta leczono erytropoetyną, po 2 latach zaś rozpoczęto terapię lenalidomidem w dawce $10 \mathrm{mg} /$ dobę przez $21 \mathrm{dni}$ w cyklach 28-dniowych. Ze względu na działania niepożądane, pod postacią biegunek oraz małopłytkowości, dawkę leku zmniejszono do $5 \mathrm{mg} /$ dobę. Po 7 miesiącach leczenia uzyskano wzrost stężenia $\mathrm{Hb}$, uniezależnienie od przetoczeń kkcz oraz całkowitą remisję cytologiczną i cytogenetyczną. Leczenie kontynuowano przez około rok. Po 14 miesiącach obserwowano nawrót choroby. Stwierdzano pogłębienie się niedokrwistości oraz małopłytkowość. W badaniu cytogenetycznym stwierdzono ewolucję klonalną 46, XX, del(5)(q13q33), del(13)(q12q14). Analiza metodą fluorescencyjnej hybrydyzacji in situ (FISH, fluorescence in situ hybridization) potwierdziła delecje 5q- oraz 13q-, odpowiednio, w $62 \%$ oraz $79 \%$ jąder komórkowych. Dodatkowo uwidoczniono trisomię chromosomu 5. w $9 \%$ jąder komórkowych. Ponownie rozpoczęto leczenie lenalidomidem, ale $z$ powodu wystąpienia cech $\mathrm{CRAB}$ zwiększono dawkę do $15 \mathrm{mg} /$ dobę. Poprawę stanu klinicznego chorego uzyskano po 4 kursach terapii. Rok po zaprzestaniu terapii w ponownie przeprowadzonym badaniu cytogenetycznym wykazano obecność dwóch niezależnych klonów komórkowych: 46,XX,del(5)(q13q33),del(13)(q12q14) — kariotyp komórek szpikowych oraz 47,X,-X,der $(1 ; 21)$ (q10,q10),-4,-4,+5,del(5),(q13q31), +7,der(7)t(1;7) $(\mathrm{p} 34.2 ; \mathrm{p} 22) \operatorname{add}(8)(\mathrm{p} 23),-13,+15, \operatorname{der}(16) \mathrm{t}(1 ; 16)$ (q23;12.2) +19,-21, + mar1, + mar2 - kariotyp komórek plazmatycznych. Ponownie zastosowano leczenie lenalidomidem, początkowo w dawce $15 \mathrm{mg} /$ dobę, następnie $25 \mathrm{mg} /$ dobę. Autorzy pracy sugerują, że brak odpowiedzi na terapię wiązał się z wystąpieniem delecji 13q-, która wyindukowała oporność na lenalidomid [33]. 


\section{Podsumowanie}

Przypadek opisanego chorego to rzadki przykład współistnienia dwóch nowotworów hematologicznych - pierwotnego MDS 5q- oraz PCM. Zastosowanie u tego chorego lenalidomidu pozwoliło na uniezależnienie się od przetoczeń kkcz, poprawę parametrów morfologii krwi, a także uzyskanie częściowej remisji cytogenetycznej MDS i częściowej remisji PCM. Prawidłowe zarządzanie działaniami niepożądanymi związanymi ze stosowaną terapią pozwoliło kontynuować leczenie lenalidomidem do dziś.

\section{Piśmiennictwo}

1. Jamroziak K. Postępy w diagnostyce i leczeniu chorych na szpiczaka plazmocytowego. Hematologia 2015; 6: 10-18.

2. Rajkumar S.V., Dimopoulos M.A., Palumbo A. i wsp. International Myeloma Working Group updated criteria for the diagnosis of multiple myeloma. Lancet Oncol. 2014; 15: e538-e548.

3. Greenberg P.L., Attar E., Bennett J.M. i wsp. Myelodysplastic syndromes: clinical practice guidelines in oncology. J. Natl. Compr. Canc. Netw. 2013; 11: 838-874.

4. Van den Berghe H., Cassiman J.J., David G. i wsp. Distinct haematological disorder with deletion of long arm of no. 5 chromosome. Nature 1974; 251: 437-438.

5. Boultwood J., Lewis S., Wainscoat J.S. The 5q- syndrome. Blood 1994; 84: 3253-3260.

6. Vardiman J.W., Harris N.L., Brunning R.D. The World Health Organization (WHO) classification of the myeloid neoplasms. Blood 2002; 100: 2292-2302.

7. Jerez A., Gondek L.P., Jankowska A.M. i wsp. Topography, clinical, and genomic correlates of $5 \mathrm{q}$ myeloid malignancies revisited. J. Clin. Oncol. 2012; 30: 1343-1349.

8. Ghosh N., Grunwald M., Fasan O., Bhutani M. Expanding role of lenalidomide in hematologic malignancies. Cancer Manag. Res. 2015; 7: 105-119.

9. Jädersten M. Pathophysiology and treatment of the myelodysplastic syndrome with isolated 5q deletion. Haematologica 2010; 95: 348-351.

10. List A., Dewald G., Bennett J. i wsp. Lenalidomide in the myelodysplastic syndrome with chromosome $5 q$ deletion. N. Engl. J. Med. 2006; 355: 1456-1465.

11. Warzocha K. Praktyczne zalecenia leczenia zespołów mielodysplastycznych ze szczególnym uwzględnieniem zastosowania lenalidomidu w przypadku obecności del(5q). Hematologia 2010; 1: 71-79.

12. Fenaux P., Giagounidis A., Selleslag D. i wsp. A randomized phase 3 study of lenalidomide versus placebo in RBC transfusion-dependent patients with low-/intermediate-1-risk myelodysplastic syndromes with del5q. Blood 2011; 118: 3765-3776.

13. Engelhardt M., Terpos E., Kleber M. i wsp. European Myeloma Network recommendations on the evaluation and treatment of newly diagnosed patients with multiple myeloma. Haematologica 2014; 99: 232-242.

14. Dmoszyńska A., Walter-Croneck A., Usnarska-Zubkiewicz L. i wsp. Zalecenia Polskiej Grupy Szpiczakowej dotyczące rozpoznawania i leczenia szpiczaka plazmocytowego oraz innych dyskrazji plazmocytowych na rok 2015. Acta Haematol. Pol. 2015; 46: 159-211.
15. Engelhardt M., Ihorst G., Landgren O. i wsp. Large registry analysis to accurately define second malignancy rates and risks in a well-characterized cohort of 744 consecutive multiple myeloma patients followed-up for 25 years. Haematologica 2015; 100: 1340-1349.

16. Hasskarl J., Ihorst G., De Pasquale D. i wsp. Association of multiple myeloma with different neoplasms: systematic analysis in consecutive patients with myeloma. Leuk. Lymphoma 2011; 52: $247-$ -259 .

17. Kyle R.A., Pierre R.V., Bayrd E.D. Multiple myeloma and acute myelomonocytic leukemia. N. Engl. J. Med. 1970; 283: 1121-1125.

18. Amiel A., Yukla M., Yogev S. i wsp. Deletion of $5 \mathrm{q} 31$ and $7 \mathrm{q} 31$ in patients with stable melphalan treated multiple myeloma. Cancer Genet. Cytogenet. 2004; 152: 84-87.

19. Morton L.M., Dores G.M., Tucker M.A. i wsp. Evolving risk of therapy-related acute myeloid leukemia following cancer chemotherapy among adults in the United States, 1975-2008. Blood 2013; 121: 2996-3004.

20. McCarthy P.L., Owzar K., Hofmeister C.C. i wsp. Lenalidomide after stem-cell transplantation for multiple myeloma. N. Engl. J. Med. 2012; 366: 1770-1781.

21. Palumbo A., Hajek R., Delforge M. i wsp. Continuous lenalidomide treatment for newly diagnosed multiple myeloma. N. Engl. J. Med. 2012; 366: 1759-1769.

22. Attal M., Lauwers-Cances V., Marit G. i wsp. Lenalidomide maintenance after stem-cell transplantation for multiple myeloma. N. Engl. J. Med. 2012; 366: 1782-1791.

23. Pemmaraju N., Shah D., Kantarjian H. i wsp. Characteristics and outcomes of patients with multiple myeloma who develop therapy-related myelodysplastic syndrome, chronic myelomonocytic leukemia, or acute myeloid leukemia. Clin. Lymphoma Myeloma Leuk. 2015; 15: 110-114.

24. Thomas A., Mailankody S., Korde N. i wsp. Second malignancies after multiple myeloma: from 1960s to 2010s. Blood 2012; 119: 2731-2737.

25. Mailankody S., Pfeiffer R.M., Kristinsson S.Y. i wsp. Risk of acute myeloid leukemia and myelodysplastic syndromes after multiple myeloma and its precursor disease (MGUS). Blood 2011; 118: 4086-4092.

26. Travis L.B., Rabkin C.S., Brown L.M. i wsp. Cancer survivorship genetic susceptibility and second primary cancers: research strategies and recommendations. J. Natl. Cancer Inst. 2006; 98: 15-25.

27. Hideshima T., Mitsiades C., Tonon G. i wsp. Understanding multiple myeloma pathogenesis in the bone marrow to identify new therapeutic targets. Nat. Rev. Cancer 2007; 7: 585-598.

28. Shibata K., Shimamoto Y., Nakazato S. i wsp. Refractory anaemia with ringed sideroblasts concurrent with multiple myeloma a brief review of the recent literature. Haematologia (Budap.) 1997; 28: 199-205.

29. Economopoulos T., Pappa V., Panani A. i wsp. Myelopathies during the course of multiple myeloma. Haematologica 1991; 76: 289-292.

30. Copplestone J.A., Mufti G.J., Hamblin T.J., Oscier D.G. Immunological abnormalities in myelodysplastic syndromes. II. Coexistent lymphoid or plasma cell neoplasms: a report of 20 cases unrelated to chemotherapy. Br. J. Haematol. 1986; 63: 149-159.

31. Florensa L., Vallespí T., Woessner S. i wsp. Incidence and characteristics of lymphoid malignancies in untreated myelodysplastic syndromes. Leuk. Lymphoma 1996; 23: 609-612.

32. Rios R., Sole F., Gascon F. Simultaneous occurrence of the 5qsyndrome and multiple myeloma. Clin. Lab. Haematol. 2000 22: 49-53.

33. Ortega M., Mallo M., Solé F. i wsp. 5q- syndrome and multiple myeloma diagnosed simultaneously and successful treated with lenalidomide. Leuk. Res. 2013; 37: 1248-1250. 